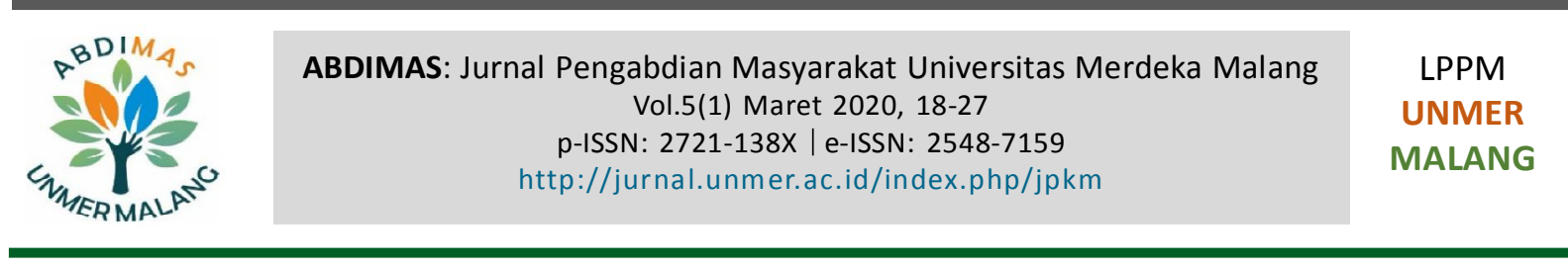

\title{
Model Pertanggungjawaban BUMDes Puji Berkah pada Unit Simpan Pinjam
}

\author{
Fatchur Rohman', Miftah Arifin ${ }^{2}$ \\ ${ }^{1}$ Departemen Akuntansi, Fakultas Ekonomi dan Bisnis, ${ }^{2}$ Departemen Manajemen Fakultas Ekonomi dan Bisnis, Universitas \\ Islam Nahdlatul Ulama, Jl. Taman Siswa, Jepara, 59451, Indonesia
}

\section{ARTICLE INFO: \\ Received: 2019-09-04 Revised: 2019-11-12 Accepted: 2020-02-03}

Keywords: Accountability information system, Financial management, Village-Owned Enterprises

\begin{abstract}
ABTRACT
This paper describes the results of community service activities (PKM) at the Village-Owned Enterprises in Jepara that face accountability issues. The purpose of this community service program is to implement the BUMDes accountability model and BUMDes business management. The program implementation phase includes systematic development of the BUMDes accountability report, application and process of preparing BUMDes accountability report, development of a Simple Financial Information System, and assistance and application of a simple financial information system. The results of the community service program outputs are generated in the form of guidelines for preparing the accountability report of BUMDes Puji Berkah Sinanggul and simple saving and loan financial applications. Based on the results of the dedication, it can be formulated that the implementation of the accountability model of BUMDes Puji Berkah can improve the quality of the performance of existing managers of BUMDes which are the object of service. BUMDes fits the format and meets the timeliness of reporting.
\end{abstract}

() 2020 Published by University of Merdeka Malang. This is an open access article distributed under the CC BY-SA 4.0 license (https://creativecommons.org/licenses/by-sa/4.0/)

How to cite: Rohman, F., \& Arifin, M. (2020). Model Pertanggungjawaban BUMDes Puji Berkah pada Unit Simpan Pinjam. Abdimas: Jurnal Pengabdian Masyarakat Universitas Merdeka Malang, 5(1), 18-27.

https://doi.org/10.26905/abdimas.v5i1.3368

\section{PENDAHULUAN}

Mekanisme good corporate governance dianggap sebagai faktor terpenting dalam menilai dan memantau keefektifan pelaporan keuangan (Mallin, 2002; Rahiim \& Wulandari, 2016; Brown, Pott, \& Wömpener, 2014; Rini, 2019). Tata kelola internal dan eksternal yang ditetapkan oleh lembaga untuk meningkatkan efisiensi dan efektivitas operasi dan mengurangi timbulnya kesalahan atau manipulasi dalam sistem akuntansi. Guna meningkatkan efisiensi dan efektivitas serta mengurangi timbulnya kesalahan dalam pengelolaan dan penyajian laporan keuangan, maka dapat dilakukan melalui implementasi sistem informasi (Halimatusadiah \& Gunwan, 2014; Lukiman \& Lestarianto, 2016).

Penggunaan teknologi informasi dalam pengelolaan keuangan Badan Usaha Milik Desa (BUMDes) di Kabupaten Jepara masih sangat terbatas. Dari 184 BUMDes yang telah berdiri mendapatkan pengesahan

Corresponding Author:

Fatchur Rohman:

Tel. +62 291595320

E-mail: fatchur@unisnu.ac.id 


\section{Model Pertanggungjawaban BUMDes Puji Berkah pada Unit Simpan Pinjam \\ Fatchur Rohman, Miftah Arifin}

dari Kementerian Hukum dan HAM hanya 10\% yang sudah menerapkan teknologi informasi dalam mengelola administrasi dan pengelolaan pertanggungjawaban keuangan. Hal ini tidak terlepas karena keterbatasan kemampuan BUMDes dalam mengadakan sarana teknologi informasi dan kemampuan sumber daya manusia yang ada di BUMDes dalam penguasaan teknologi informasi yang masih minim. Di sisi lain teknologi informasi yang sudah berkembang dengan cepat untuk memenuhi kebutuhan manajemen bisnis, serta dapat memberi kemudahan dalam hal pengendalian keuangan (Sugiantina, 2011)

Salah satu potensi Desa Sinanggul Kecamatan Mlonggo Kabupaten Jepara mempunyai wilayah seluas 554,159 km² yang mempunyai jumlah penduduk pada awal tahun 2015 ini 13.211 jiwa. Dukungan masyarakat Desa Sinanggul Kecamatan Mlonggo Kabupaten Jepara sangat tinggi untuk membangun lingkungan. Dukungan tersebut berupa adanya kesanggupan warga untuk mengeluarkan swadaya dalam pembangunan tersebut. Salah satu kegiatan yang bentuk oleh desa berdasarkan UU adalah membentuk Badan Usaha Milik Desa (BUMDes). Dan Bumdes Puji Berkah didirikan pada tanggal 17 Oktober 2013 dan di Resmikan dengan badan hukum 518/271/BH/XIV.10///2014.

Jumlah masyarakat tersebut yang menjadi sasaran BUMDes Puji Berkah Sinanggul. Sektor usaha yang dikerjakan oleh badan usaha tersebut ada berbagai macam. Untuk itu BUMDes Puji Berkah dalam menjalankan usahanya memiliki beberapa sektor usaha antara lain: perdagangan, pengelolaan pasar, penyewaan tempat olahraga, lumbung pangan desa, pariwisata, dan unit keuangan simpan pinjam.

Berdasarkan kondisi tersebut, maka unit keuangan simpan pinjam perlu memiliki Pedoman Standar Operasional Prosedur Usaha Simpan Pinjam. Diharapkan Pedoman Standar Operasional Prosedur tersebut dapat digunakan sebagai salah satu acuan dalam pengelolaan usaha simpan pinjam oleh unit keuangan simpan pinjam, sehingga usaha simpan pinjam pada BUMDES Puji Berkah dapat ditangani secara profesional. Perlunya Pedoman Standar Operasional Prosedur ini bertujuan untuk memberikan panduan bagi pengelola unit keuangan simpan pinjam dalam menjalankan kegiatan operasional usaha simpan pinjam secara profesional, transparan dan akuntabel baik bagi pihak internal maupun pihak eksternal lembaga keuangan mikro. Maka dari itu untuk implementasi PP No. 9 Tahun 1995, Departemen Koperasi dan Usaha Kecil Menengah perlu mengeluarkan berbagai kebijakan untuk mendukung kelangsungan kehidupan lembaga keuangan mikro dalam menjalankan kegiatan simpan pinjam.

Pengelola BUMDes Puji Berkah masih mengandalkan kemampuan individu dari pengelola sehingga belum ada standar baku yang digunakan, sehingga ketika pengelola yang bertanggung jawab tidak ada di kantor maka kegiatan di Bumdes Puji Berkah tidak terkontrol dengan baik, sehingga ketika ada keinginan pendampingan dari dosen dalam rangka pengembangan dan pembuatan sistem akuntansi dan keuangan serta standar operasional maka pengelola akan sangat terbantu, karena diharapkan nantinya akan ada standar operasional maupun sistem akuntansi dan keuangan yang memudahkan pengelola maupun pengurus untuk mengontrol keuangan maupun karyawan guna mengambil keputusan yang dapat memajukan unit keuangan simpan pinjam (Tumbel, Tumbel, \& Palandeng, 2016). Penerapan sistem informasi akuntansi sangat berhubungan dengan kualitas penyusunan laporan keuangan (Juwita, 2013; Ikriyati \& Aprila, 2019).

Berdasarkan hasil survei ternyata unit keuangan simpan pinjam BUMDes Puji Berkah belum memiliki prosedur dan standar operasional dalam menjalankan unit keuangan simpan pinjam serta model pertanggungjawaban keuangan yang dapat membantu kegiatan pelayanan unit keuangan simpan pinjam BUMDes Puji Berkah Sinanggul.

Persyaratan penting yang perlu dimiliki oleh unit keuangan simpan pinjam sebagai unit keuangan ialah harus menjaga kredibilitas atau kepercayaan dari stakeholder pada khususnya dan/atau masyarakat 
ABDIMAS: Jurnal Pengabdian Masyarakat Universitas Merdeka Malang

Volume 5, No 1, Maret 2020: 18-27

luas pada umumnya. Namun demikian untuk melaksanakan perannya sebagai unit keuangan, unit keuangan simpan pinjam masih dihadapkan pada berbagai kendala yang disebabkan oleh hal-hal sebagai berikut: (1) belum adanya kesamaan sistem dan prosedur dalam operasional manajemen kelembagaan, manajemen usaha dan manajemen keuangan. (2) Belum adanya standar sistem dan prosedur dalam operasional manajemen kelembagaan, manajemen usaha dan manajemen keuangan.

Keberadaan unit keuangan simpan pinjam tersebut sangat dirasakan manfaatnya bagi masyarakat karena dapat membantu dalam simpanan baik simpanan harian yang jumlahnya kecil tetapi dapat rutin dilakukan, selain itu masyarakat juga terbantu dengan bantu permodalan dalam hal ini rata-rata adalah pengrajin meubel, pedangan kayu, maupun pedagang eceran yang ada di Jepara. Meskipun saat ini pengelolaannya masih sangat sederhana tetapi kedua unit keuangan simpan pinjam tersebut dapat menarik calon anggota yang cukup Kecamatan Mlonggo dan Pecangaan banyak, tetapi tidak sedikit pula yang ragu untuk simpan maupun pinjam dari kedua unit keuangan simpan pinjam tersebut karena belum memiliki sistem akuntansi maupun keuangan yang jelas. Rata-rata khawatir jika terjadi kekeliruan dalam pencatatan maupun dalam perhitungan, sehingga lebih memilih untuk menyimpan maupun meminjam keuangan ke lembaga keuangan yang lain.

Dalam praktiknya penyelenggaraan kegiatan simpan pinjam yang diselenggarakan oleh BUMDes banyak permasalahan yang dihadapi. Adapun persoalan yang dihadapi oleh mitra yaitu berkaitan dengan masalah pengelolaan administrasi, secara umum menjadi kendala mitra, meskipun sudah dikelola namun masih manual, hal ini menjadikan kendala ketika menyusun laporan ataupun dalam kebijakan pengambilan keputusan. Dalam pelaksanaan pengelolaan administrasi juga sangat tergantung kepada petugas administrasi yang jumlah dan kemampuanya masih terbatas.

Untuk itu perlu dikembangkan sebuah sistem informasi pertanggunjawaban yang dapat menunjang pengelolaan administrasi secara terkomputerisasi, sehingga pengelolaan administrasi dapat dilaksanakan secara efektif dan efisien. Pengembangan sistem informasi saat ini sudah menjadi kebutuhan, hanya saja mitra menghadapi kendala berkaitan dengan anggaran dan sumber daya manusia yang melakukan pengembangan dan pengelolaannya, untuk itu bersama mitra sepakat untuk menyelesaikan permasalahan pengelolaan administrasi melalui pengembangan sistem informasi manajemen tatakelola kelembagaan terpadu berbasis teknologi informasi dan komunikasi melalui program PKM Unisnu.

Berkaitan dengan pengelolaan dan pelaporan keuangan persoalan yang dihadapi adalah pengembangan BUMDes yang ada di bawah pemerintah desa tersebut sangat lamban, hal ini dikarenakan informasi yang berkaitan dengan keuangan kurang akurat. Penyebabnya diantaranya karena pelaporan keuangan masih menggunakan pelaporan secara manual, administrasi dan tatakelola keuangan yang dilakukan masih menggunakan catatan manual, serta penyusunan pelaporan keuangan belum sesuai standar akuntansi.

\section{METODE}

Metode pelaksanaan program dilaksanakan melalui tahapan sebagai berikut: (1) Pengembangan sistem informasi BUMDes (SILKM); (2) Penerapan dan proses implementasi aplikasi SILKM; (3) Penyusunan prosedur mutu tatakelola keuangan; (4) Implementasi prosedur mutu tatakelola keuangan; (5) Pendampingan dan penerapan manajemen tatakelola keuangan.

Proses pengembangan sistem yang dilaksanakan menggunakan pendekatan system development life cycle/SDLC (Jogiyanto, 2009), melalui tahapan: (1) studi pendahuluan; (2) studi kelayakan; (3) memahami sistem yang ada; (4) perancangan sistem; (5) implementasi dan operasional sistem. Sedangkan dalam 


\section{Model Pertanggungjawaban BUMDes Puji Berkah pada Unit Simpan Pinjam \\ Fatchur Rohman, Miftah Arifin}

proses identifikasi masalah menggunakan kerangka PIECES (Performance, Information, Economic, Control, Efficiency dan Service).

Sesuai dengan pendekatan pengembangan system model SDLC maka dalam kegiatan pengembangan dan implementasi sistem informasi manajemen BUMDes (SILKM) dilaksanakan dengan tahapan sebagai berikut: (1) Melakukan analisis sistem, mengidentifikasi permasalahan dan kebutuhan pemakai; (2) Perancangan sistem; (3) Pengembangan sistem; (4) Membuat buku manual sistem informasi manajemen tatakelola kelembagaan; (5) Pelatihan operasional penggunaan Software bagi tenaga operator pelaksana sistem nantinya; (6) Penerapan dan pendampingan dalam menggunakan sistem di tempat mitra.

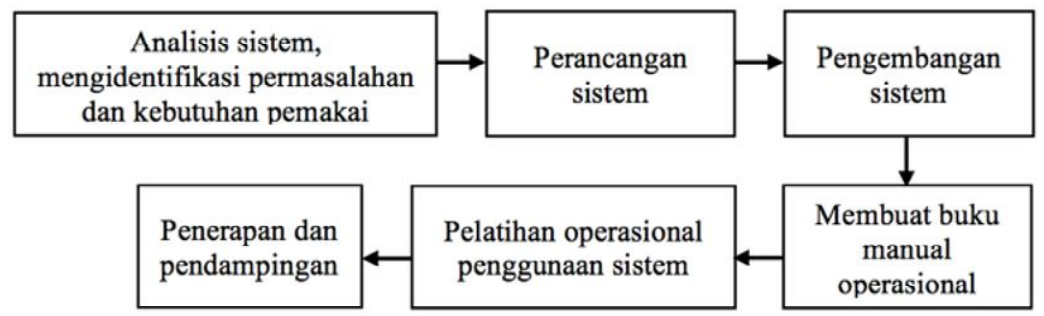

Gambar 1. Alur kegiatan pengembangan dan implementasi sistem informasi BUMDes (SILKM)

Sedangkan kegiatan penyusunan sistem manajemen mutu tatakelola kelembagaan dilaksanakan melalui tahapan sebagai berikut: (1) Gap analisis sistem manajemen tatakelola kelembagaan, kegiatan ini bertujuan untuk menemukan kelemahan dan kekuatan dari sistem tatakelola manajemen di tempat mitra, serta prespektif kedepan yang akan dicapai oleh mitra; (2) Analisis data dari hasil gap analisis; (3) Workshop hasil gap analisis untuk mendapatkan masukkan baik dari pimpinan maupun dari pelaksana, workshop diharapkan dapat digunakan sebagai bahan untuk penyusunan sistem Tatakelola manajemen sekolah, workshop ini bertujuan sebagai bahan menyusun draft rancangan sistem manajemen mutu tatakelola kelembagaan serta tentang isu-isu strategis, kondisi mitra dan arah pengembangan menuju sekolah ke depan; (4) Penyusunan rancangan sistem manajemen tatakelola kelembagaan; (5) Workshop hasil rancangan sistem, workshop ini bertujuan untuk mendapatkan masukan untuk perbaikan selanjutnya; (6) Sosialisasi kepada seluruh komponen yang ada di mitra; (7) Penerapan dan pendampingan dalam menggunakan Sistem manajemen tatakelola kelembagaan di tempat mitra.

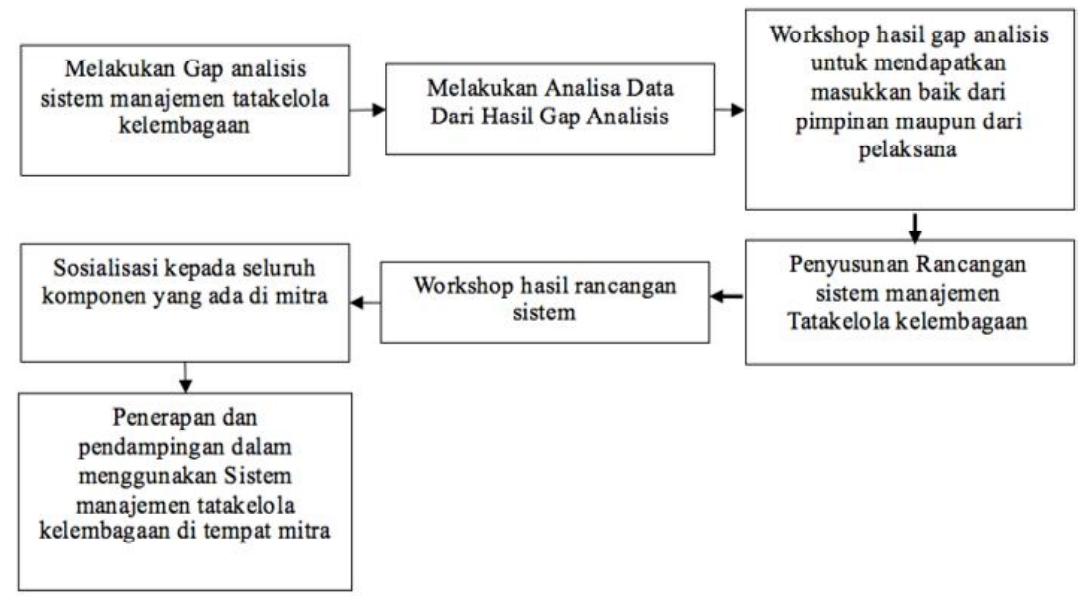

Gambar 2. Alur kegiatan penyusunan sistem manajemen mutu tatakelola kelembagaan 
ABDIMAS: Jurnal Pengabdian Masyarakat Universitas Merdeka Malang Volume 5, No 1, Maret 2020: 18-27

\section{HASIL DAN PEMBAHASAN}

Kegiatan pengabdian kepada masyarakat yang dilaksanakan di BUMDes Puji Berkah Sinanggul, dengan program sebagai berikut: (1) Kegiatan survei awal dan persiapan pelaksanaan pengabdian; (2) Pengembangan sistem informasi BUMDes; (3) Penyerahan peralatan; (4) Pelatihan sistem informasi BUMDes; dan (5) Penyusunan dokumen sistem manajemen mutu BUMDes.

\section{Kegiatan survei awal dan persiapan pelaksanaan pengabdian}

Pada kegiatan ini dilakukan pertemuan awal dengan perwakilan Pemerintah Desa Sinanggul yaitu Petinggi Sinanggul A. Sholeh (Gambar 3), pertemuan tersebut menghasilkan rencana kegiatan pengabdian berupa kegiatan pengembangan sistem informasi BUMDes, penyusunan manajemen mutu pengelolaan keuangan; pengadaan peralatan serta pelatihan dan rencana implementasi dari pengembangan sistem tersebut.

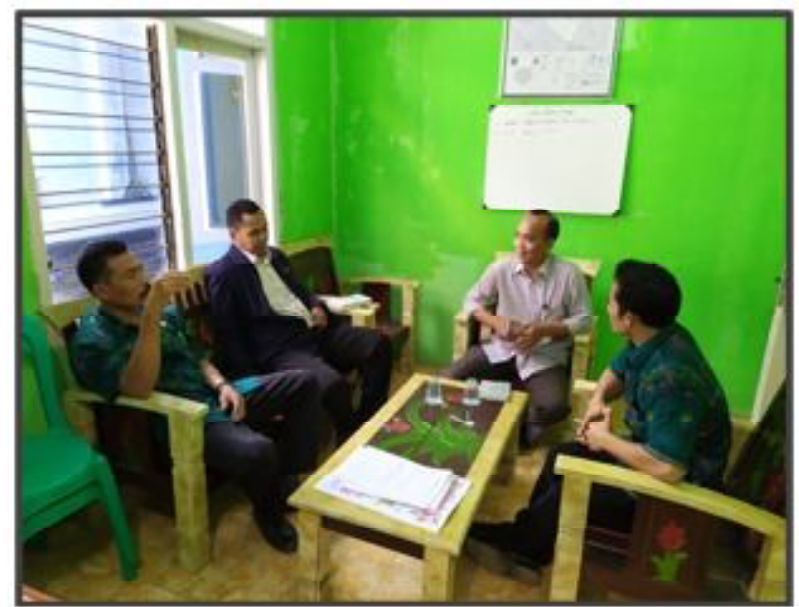

Gambar 3. Kegiatan survey awal dengan Pemerintah Desa Sinanggul

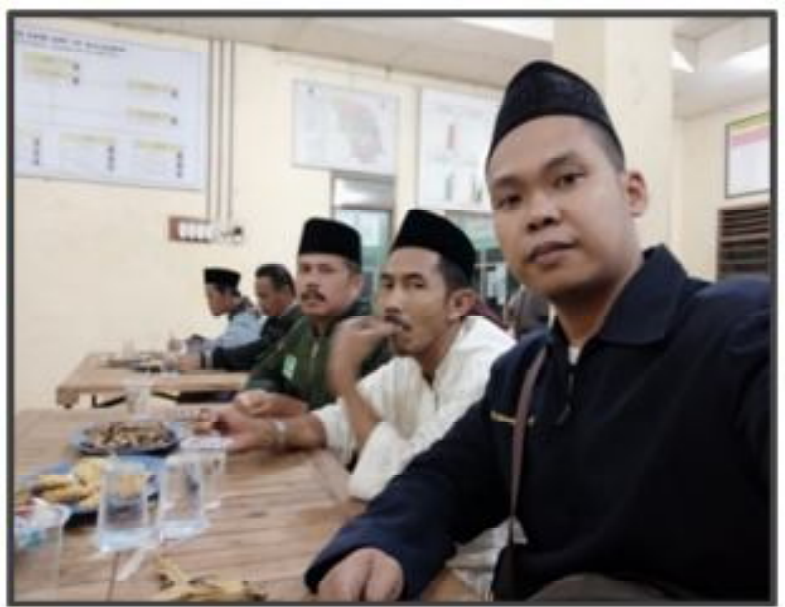

Gambar 4. Kegiatan FGD dengan BPD Desa Sinanggul

\section{Penyusunan sistem informasi BUMDes (SILKM)}

Penyusunan sistem informasi BUMDes, tahap awal pelaksanaan yaitu melakukan studi pendahuluan, melalui identifikasi berkaitan dengan jenis, ruang lingkup dan pemahaman awal dari pengembangan sistem informasi unit simpan pinjam BUMDes. Dari studi pendahuluan ini diperoleh hasil ruang lingkup sistem yang akan disusun yaitu meliputi kebutuhan data nasabah, data pengelola, jenis transaksi dan angsuran dan pelaporan keuangan dan akuntansi.

Tahap berikutnya yaitu melakukan studi kelayakan utamanya berkaitan dengan aspek teknologi dan operasional. Dalam hal ini didapatkan hasil pengembangan sistem dengan framework Code lgniter, dari sisi kelayakan operasional memiliki performa lebih cepat, konfigurasi yang minim serta dokumentasi yang lengkap.

Kemudian mengidentifikasi permasalahan dan menginventarisasi kebutuhan informasi pemakai, dengan mempelajari proses bisnis yang dijalankan, mengidentifikasi permasalahan yang muncul dari proses 


\section{Model Pertanggungjawaban BUMDes Puji Berkah pada Unit Simpan Pinjam \\ Fatchur Rohman, Miftah Arifin}

bisnis tersebut dan memperbaiki proses bisnis yang ada. Memahami sistem yang pada prinsipnya adalah melakukan analisis kebutuhan sistem dengan menitikberatkan pada bagaimana mengidentifikasi masalah dari sistem lama yang digunakan sebelumnya, hal ini agar permasalahan yang muncul pada sistem yang lama dapat diperbaiki di sistem yang baru.

Mengidentifikasi masalah dilakukan dengan mengidentifikasi akar masalah, merupakan sumber dari permasalahan yang harus diperbaiki. Untuk mengidentifikasi masalah menggunakan cara analisis dengan kerangka PIECES (Performance, Information, Economic, Control, Efficiency dan Service) (Fatta, 2007). Kerangka PIECES digunakan untuk mengkategorikan permasalah sesuai dengan data yang dikumpulkan.

Performance (kinerja), ditemukan permasalahan utamanya berkaitan dengan penyusunan laporan keuangan dari masing-masing unit tidak terdapat kesesuaian format dan sering terjadi keterlambatan. Ketidaksesuaian format menjadikan laporan sulit dianalisis dan keterlambatan pengiriman laporan dikarenakan proses penyusunan laporan masih dilakukan secara manual sehingga berpotensi menimbulkan kesalahan dan membutuhkan waktu yang cukup lama.

Information (informasi), informasi berkaitan dengan perkembangan masing-masing lembaga di bawah pengelolaan yayasan kurang terjamin. Keakurasian berkaitan dengan penyajian data keuangan belum sesuai dengan standar akuntansi, data tagihan keuangan dan pembayaran oleh peserta didik. Kurang terjaminnya informasi dan pelaporan keuangan yang belum standar akuntansi, karena data diproses secara manual, sehingga sering dijumpai adanya selisih serta penyajian informasi berlangsung lama.

Economic (ekonomi), dari aspek ekonomi, data keuangan utamanya data tagihan dan pembayaran dari peserta didik belum dikelola dengan baik, berpotensi terjadinya kerugian, serta perencanaan dan pengelolaan keuangan tidak dapat dilakukan dengan baik.

Control (pengendalian), permasalahan yang ditemukan berkaitan dengan penyimpanan file/dokumen, kerahasiaan tidak terjamin dan tidak dikoordinasikan dengan baik, dokumen tercecer pada beberapa komputer mengikuti dimana staf saat itu bekerja, dokumen hilang terhapus atau terkena virus, belum dilakukannya backup data dengan baik.

Efficiency (efisiensi), media komunikasi dan penyampaian informasi pihak pengelola BUMDes dilakukan dengan buku penghubung, undangan, pengumuman di mading, pengumuman langsung ke masyarakat di Sinanggul atau pihak penerima manfaat harus data ke kantor BUMDes.

Service (pelayanan), pelayanan sangat tergantung dengan staf bagian Administrasi, apabila terdapat salah satu staf yang tidak masuk menjadikan pelayanan terganggu utamanya pelayanan pada bagian keuangan, serta pelayanan tergantung pada jam layanan.

Dari hasil analisis sistem yang telah dilakukan, kemudian dilakukan perancangan sistem dan pembuatan system dan sistematika pertanggungjawaban BUMDes yang sesuai dengan kebutuhan komisaris, pengawas dan masyarakat lainnya. Pada kegiatan ini dilakukan pertemuan dengan perwakilan masyarakat Desa Sinanggul yaitu Anggota BPD Sinanggul (Gambar 4), pertemuan tersebut menghasilkan rancangan sistematika laporan pertanggungjawaban BUMDes pada unit simpan pinjamnya, pelatihan penyusunan dokumen pertanggungjawaban dan penyampaian pertanggungjawaban BUMDes kepada para stakeholders (Gambar 5). 
ABDIMAS: Jurnal Pengabdian Masyarakat Universitas Merdeka Malang Volume 5, No 1, Maret 2020: 18-27

\section{Pendampingan dan penerapan pertanggungjawaban BUMDes}

Pendampingan dilaksanakan untuk memastikan bahwa sistematika pelaporan pertanggungjawaban yang disusun telah dilaksanakan oleh pengelola BUMDes dengan baik. Dengan dilaksanakannya pendampingan tersebut pengelola BUMDes merasa terbantu dalam melaksanakan pekerjaan yang sesuai dengan standar operasional. Pengelola merasa tidak terbebani oleh prosedur yang telah disusun, karena Prosedur laporan pertanggungjawban disusun dengan memperhatikan masukan dari pengelola tentang cara kerja yang ada di BUMDes.

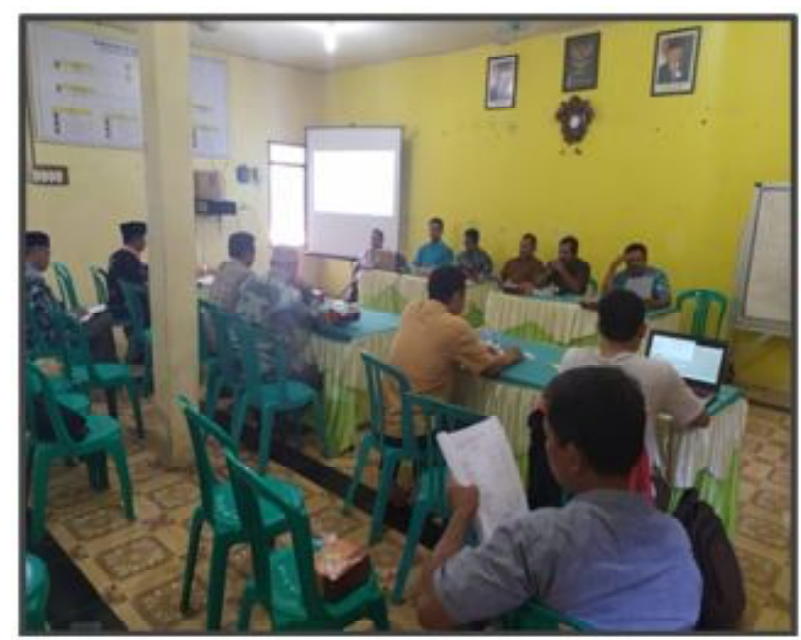

Gambar 5. Kegiatan Pelaporan Pertanggungjwaban BUMDes Desa Sinanggul

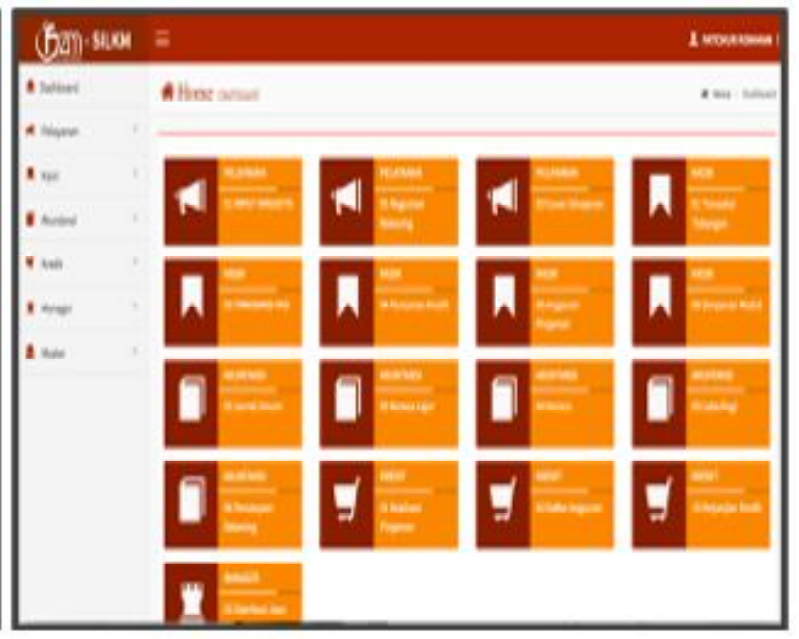

Gambar 6. Dashboard Sistem Informasi BUMDes (SILKM

\section{Penerapan dan proses implementasi aplikasi BUMDes}

Implementasi sistem bertujuan untuk melakukan proses penerapan sistem baru supaya siap dioperasikan (Gambar 6). Tahap implementasi sistem yang dilaksanakan melalui beberapa tahapan, yaitu: (1) mempersiapkan rencana implementasi; (2) melakukan kegiatan implementasi; dan (3) menindaklanjuti implementasi (Jogiyanto, 2009).

Kegiatan implementasi sistem didahului dengan melatih personil yang ditunjuk sebagai administrator dan operator sistem, memilih dan mempersiapkan tempat dan lokasi sistem dalam hal ini ditempatkan pada sebuah komputer server yang telah disiapkan (Gambar 7). Sedangkan untuk proses konversi data dilaksanakan secara langsung, karena dari mitra BUMDes sebelumnya belum memiliki basis data yang tersimpan di server, data-data yang ada konversi dari file-file yang tersimpan di Ms Excel, Ms Word maupun laporan cetak. 


\section{Model Pertanggungjawaban BUMDes Puji Berkah pada Unit Simpan Pinjam \\ Fatchur Rohman, Miftah Arifin}

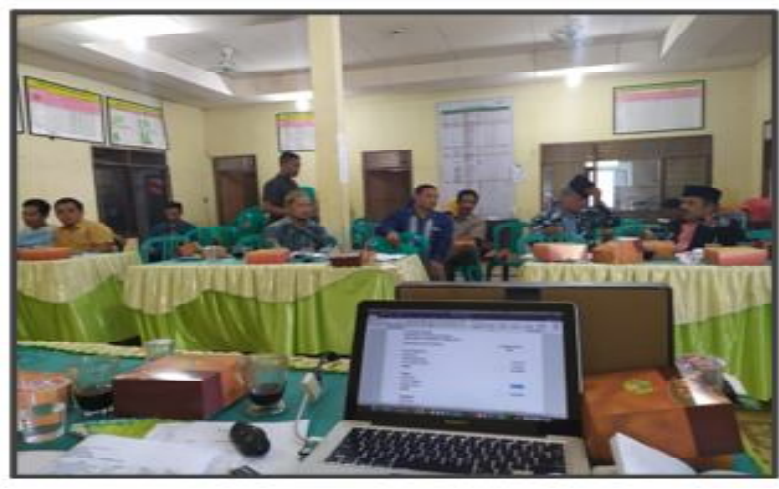

Gambar 7. Administrator SILKM di BUMDes Puji Berkah menjalankan sistem

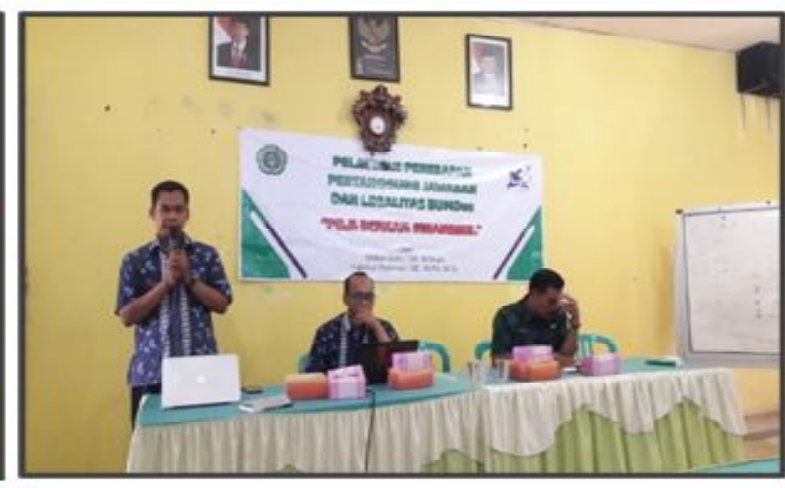

Gambar 8. Pelatihan penerapan pertanggungjawaban BUMDes Puji Berkah Sinanggul

\section{Penyusunan dan implementasi prosedur mutu}

Penyusunan prosedur mutu dimulai dengan menggali informasi di BUMDes, dengan melakukan koordinasi dan mengindefikasi kebutuhan BUMDes, selain itu diidentifikasi alur kerja yang ada di BUMDes. Setelah diketahui data yang dibutuhkan dan alur kerja maka pelaksana kemudian melakukan penyusunan panduan kerja yang terangkum dalam prosedur mutu. Penyelesaian prosedur mutu dengan melibatkan pengelola dan pengurus BUMDes untuk mendapatkan informasi alur kerja maupun ketentuan-ketentuan dalam menjalankan manajerial BUMDes sehingga prosedur mutu akan dapat diaplikasikan sebagai acuan kerja.

Sosialisasi prosedur mutu dilakukan kepada pengurus maupun pengelola BUMDes untuk memudahkan pengurus dan pengelola mengerti isi dan ketentuan-ketentuan yang ada dalam prosedur mutu yang telah disusun. Selain itu dalam sosialisasi juga mendengarkan masukan-masukan yang dapat digunakan untuk memperbaiki standar kerja yang telah dibuat. Sosialiasi bertujuan untuk memberikan informasi yang ada di prosedur mutu yang telah disusun dengan adanya sosialisasi prosedur mutu tersebut terlihat jelas bahwa pengurus maupun pengelola BUMDes mampu memahami dengan baik, hal ini terlihat karena dilibatkannnya sebagian pengurus maupun pengelola yang menyusun prosedur mutu.

\section{SIMPULAN DAN SARAN}

\section{Simpulan}

Seluruh tahapan program pengabdian masyarakat meliputi pengembangan sistem informasi BUMDes (SILKM); penerapan dan proses implementasi aplikasi BUMDes; penyusunan prosedur mutu tatakelola keuangan; Implementasi prosedur mutu tatakelola keuangan; serta pendampingan dan penerapan manajemen tatakelola keuangan telah dilaksanakan dengan baik, dengan output luaran berupa aplikasi BUMDes versi 0.1 dan dokumen sistematika pertanggungjawaban BUMDes. Pengelolaan keuangan unit simpan pinjam BUMDes saat ini telah menggunakan sistem terkomputerisasi, melalui implementasi SILKM maka akan dapat meningkatkan efisiensi dan efektivitas operasi dan mengurangi timbulnya kesalahan atau manipulasi dalam sistem akuntansi. Laporan keuangan telah disajikan dengan baik, tepat waktu dan akurat melalui sistem. Mekanisme pengelolaan keuangan dan kelembagaan telah diatur melalui berbagai prosedur 
ABDIMAS: Jurnal Pengabdian Masyarakat Universitas Merdeka Malang

Volume 5, No 1, Maret 2020: 18-27

mutu yang telah disusun, hal ini menunjukkan pelaksanaan tatakelola kelembagaan yang baik. Dengan implementasi tata kelola kelembagaan yang baik maka akan meningkatkan efisiensi dan efektivitas serta mengurangi timbulnya kesalahan dalam pengelolaan BUMDes.

\section{Saran}

Administrator sistem yang telah ditunjuk agar dapat mengkoordinasikan penggunaan SILKM kepada seluruh user/pengguna sistem, untuk berjalannya aktivitas pengelolaan keuangan melalui implementasi sistem informasi. SILKM selanjutnya agar dapat dikembangkan lagi sesuai kompleksitas kebutuhan pengelolaan keuangan yang ada di BUMDes, dalam hal ini dapat bekerjasama dengan pihak UNISNU Jepara maupun pihak-pihak lainnya yang bergerak dalam bidang pengembangan system informasi. Prosedur Mutu pengelolaan keuangan dan kelembagaan BUMDes agar dapat dilaksanakan secara konsisten, dan dilakukan perbaikan pada berbagai proses yang dirasa sudah tidak lagi sesuai dengan kompleksitas pengelolaan keuangan dan kelembagaan, serta ke depan perlu dilakukannya peninjauan prosedur secara berkala sehingga ada perbaikan berkelanjutan atas proses yang berjalan.

\section{UCAPAN TERIMAKASIH}

Program pengabdian yang dilaksanakan merupakan skema pengabdian Program Kemitraan Masyarakat (PKM). Dengan telah selesainya program kami tim pengabdian mengucapkan terimakasih kepada: (1) Lembaga Penelitian dan Pengabdian Kepada Masyarakat (LPPM) Universitas Islam Nahdlatul Ulama (UNISNU) Jepara yang telah mengkoordinir pelaksanaan kegiatan pengabdian kepada masyarakat; (2) Petinggi Desa Sinanggul, Direktur BUMDes Pujiberkah Sinanggul, BPD Sinanggul, sebagai mitra program dalam pelaksanaan program PKM, dan telah secara aktif ikut berpartisipasi dalam program pengabdian ini.

\section{DAFTAR PUSTAKA}

Brown, N. C., Pott, C., \& Wömpener, A. (2014). The effect of internal control and risk management regulation on earnings quality: Evidence from Germany. Journal of Accounting and Public Policy, 33(1), 1-31. https://doi.org/10.1016/j.jaccpubpol.2013.10.003

Fatta, H. A. (2007). Analisis dan Perancangan Sistem Informasi untuk Keunggulan Bersaing Perusahaan dan Organisasi Modern. Edisi Kesatu. Yogyakarta: CV. Andi Offset.

Halimatusadiah, E., \& Gunwan, B. (2014). Analisis penerapan good corporate governance dalam mengoplimalkan pelaksanaan sistem informasi akuntansi. Jurnal Riset Akuntansi dan Keuangan, 2(1), 300-313. https://doi.org/10.17509/jrak.v2i1.6583

Ikriyati, T., \& Aprila, N. (2019). Pengaruh penerapan standar akuntansi pemerintah, implementasi sistem informasi manajemen daerah, dan sistem pengendalian internal pemerintah terhadap kualitas laporan keuangan Pemerintah Daerah Kabupaten Seluma. Jurnal Akuntansi, 9(2), 131-140. https://doi.org/10.33369/j.akuntansi.9.2.131-140

Jogiyanto. (2009). Sistem Teknologi Informasi. Edisi Ketiga. Yogyakarta: Andi Publishing.

Juwita, R. (2013). Pengaruh implementasi standar akuntansi pemerintahan dan sistem informasi akuntansi terhadap kualitas laporan keuangan. Trikonomika, 12(2), 201-214. http://dx.doi.org/ 10.23969/trikonomika.v12i2.480. 


\section{Model Pertanggungjawaban BUMDes Puji Berkah pada Unit Simpan Pinjam}

Fatchur Rohman, Miftah Arifin

Lukiman, R., \& Lestarianto, J. W. (2016). Pengaruh penerapan sistem informasi akuntansi, pemanfaatan sistem informasi, efektivitas penggunaan sistem informasi akuntansi, kepercayaan atas teknologi sistem informasi akuntansi, dan teknologi informasi terhadap kinerja individu karyawan. Jurnal Ultima Accounting, 8(2), 46-65. https://doi.org/10.31937/ akuntansi.v8i2.581

Mallin, C. (2002). The relationship between corporate governance, transparency and financial disclosure. Corporate Governance, 10(4), 253-255.

Rahiim, D., \& Wulandari, S. (2016). Pengaruh mekanisme corporate governance dan kualitas kantor akuntan publik terhadap integritas laporan keuangan. Esensi, 4(3), 87-102. https:// doi.org/10.15408/ess.v4i3.2436

Rini, R. (2019). Pengaruh penerapan peran komite audit, peran dewan pengawas syariah dan efektivitas pengendalian intern atas pelaporan keuangan terhadap kualitas pelaporan keuangan. Jurnal Akuntansi dan Keuangan Islam, 2(2), 143-155. https://doi.org/10.35836/ jakis.v2i2.49

Sugiantina. (2011). Penerapan sistem informasi dalam praktek laporan keuangan sederhana teknologi. Jurnal IImiah Sistem Informasi, 1(1), 45-52. https://doi.org/10.26594/ teknologi.v1i1.52

Tumbel, C. M., Tumbel, A. L., \& Palandeng, I. D. (2016). Penerapan sistem manajemen mutu dalam meningkatkan kinerja operasional koperasi simpan pinjam (Studi pada Koperasi Glaistygil Manado). Jurnal Berkala IImiah Efisiensi, 16(3), 14-26. 